\title{
Branched alkanes with quaternary carbon atoms from the lacustrine sediments in Linxia Basin, NE Tibetan Plateau
}

\author{
D. X. $\mathrm{HE}^{1}$ AND Y. J. TANG ${ }^{1}$
}

${ }^{1}$ Key Laboratory of Exploration Technologies for Oil and Gas Resources (Yangtze University), Ministry of Education, Wuhan, China

(hedaxiang127@163.com, tyj@yangtzeu.edu.cn)

\section{Introduction}

The application of branched alkanes with quaternary carbon atoms(BAQCs) ${ }^{[1]}$ in the study of climate changes has scarcely been reported ${ }^{[2]}$. The occurrence and distribution patterns of BAQCs in a series lacustrine sediment samples in the MaoGou section were determined in this study. The results show that these branched alkanes can be used as effective proxies for the reconstruction of a long-term climate change in the Northwest China from the Middle Miocene to the Early Pliocene (13.0 to $4.3 \mathrm{Ma}$ ).

\section{Results and Discussion}

The similarity in the changing trend of the paleoenvironmental distribution of BAQCs suggest that series $\mathrm{A}(5,5-\mathrm{DEA}), \mathrm{B}(6,6-\mathrm{DEA})$ and $\mathrm{C}(5-\mathrm{B}-5$-EAs) own the same organic matter origin, which remains enigmatic.

The relatively higher ratios of $\mathrm{A}_{23-27} /\left(\mathrm{nC}_{22}+\mathrm{nC}_{24}+\mathrm{nC}_{26}\right)$,

$\mathrm{B}_{20-26} /\left(\mathrm{nC}_{19}+\mathrm{nC}_{21}+\mathrm{nC}_{23}+\mathrm{nC}_{25}\right)$, and $\mathrm{C}_{23-27} /\left(\mathrm{nC}_{22}+\mathrm{nC}_{24}+\mathrm{nC}_{26}\right)$ compared to the other samples in MG4 (9.42 Ma), MG8 (7.87 Ma), MG12 (6.27 Ma), and MG16 (6.92 Ma) suggest that bacteria and algae were the primary origins for lacustrine sediments with the retreat of the paleolake level under relatively warm and wet climate conditions. In addition, the relatively lower ratios of $\mathrm{A}_{23-27} /\left(\mathrm{nC}_{22}+\mathrm{nC}_{24}+\mathrm{nC}_{26}\right)$,

$\mathrm{B}_{20-26} /\left(\mathrm{nC}_{19}+\mathrm{nC}_{21}+\mathrm{nC}_{23}+\mathrm{nC}_{25}\right)$, and $\mathrm{C}_{23-27} /\left(\mathrm{nC}_{22}+\mathrm{nC}_{24}+\mathrm{nC}_{26}\right)$ compared to the other samples in MG3 $(10.77 \mathrm{Ma})$, MG6 (8.72 Ma), MG10 (7.17 Ma), and MG15 (6.45 Ma) suggest that high plants were the primary origins during cold, arid periods.

\section{Conclusion}

The molecular distributions of BAQCs exhibit good agreement with the temporal distributions of climate. The long-time high-resolution spectral analysis substantiates that the NE Tibetan Plateau exhibited a rapid drying trend at approximately $8 \mathrm{Ma}$ and four major wetting intervals during 13.0 4.3 Ma, which occurred in 9.42 Ma, 7.87 Ma, 6.92 Ma, and 6.27 Ma.

[1] Kenig, F., et al. (2002). Geochim Cosmochim Ac 66(15A), A393. [2] Bai, Y., et al. (2006). Chinese Sci Bull 51, 1-8. 